\title{
An unusual vesiculous lesion of the tongue, what is your diagnosis?
}

\section{Issoual K ${ }^{1 *}$, Chaoui $R^{1}$, Dahhouki $\mathrm{S}^{1}$, Douhi $Z$, Elloudi S, Bay Bay $\mathrm{H}^{1}$, Mernissi FZ¹, Aouinti $\mathrm{L}^{2}$, Arioua $\mathrm{A}^{2}$, Ouattassi $\mathrm{N}^{2}$ and El Alami Mn ${ }^{2}$}

${ }^{1}$ Department of Dermatology, Hassan II Hospital University, Fez. Morocco

${ }^{2}$ Department of Otorhino-Laryngology and Cervico-Facial Surgery, Hassan II Hospital University, Fez. Morocco

Young patient of 13 years, in good health, consults for asymptomatic lesions of the tongue evolving since birth.

On examination, we noted, on the dorsal surface of the tongue, a hypertrophic plaque, made of multiple yellowish and translucent vesicles, they are hematic in places, the lesion overflowed on the free edge, without reaching the floor of the tongue. No deep mass was found.

The dermoscopy showed multiple yellow and translucent lacunas separated by pale septa, some of them are reddish or hematic (lagoons), with thin linear vessels. No other lesions were noted elsewhere in the oral mucosa.

At the level of the chin, we objectified a small plates of $1 \mathrm{~cm}$, slightly indurated, not keratotic, and surmounted by small clear vesicles; without mass beneath.

\section{What is your diagnosis?}

Answer: It is a microcystic lymphatic malformation or Lymphangioma circumscriptum, a very rare congenital malformation of the lymphatic vessels in soft tissues, including the skin. It is a benign condition, it can be isolated or associated with the deep type (macro or microcystic).

The positive diagnosis is supported by magnetic resonance imaging (MRI) to determine the extent of the deep lesions.

Unlike the deep and macrocystic type, inflammatory attacks are exceptional, and their prognosis good.

There exist multiple therapeutic options, starting with therapeutic abstention in small lesions, surgery, sclerotherapy and electrocoagulation, the CO2 laser (Figures 1-5).

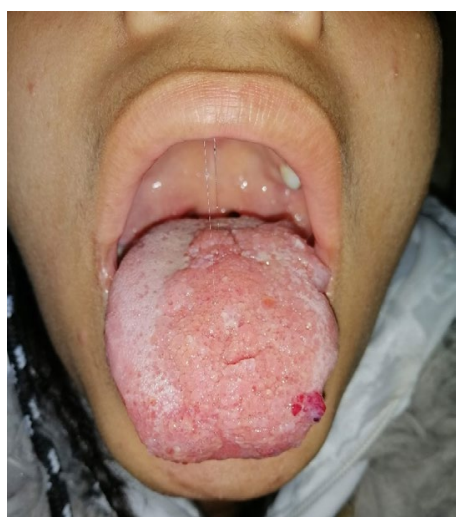

Figure 1. On the tip and ventral surface of the tongue, there are some vesicles of the same characteristics, without lesions on the floor

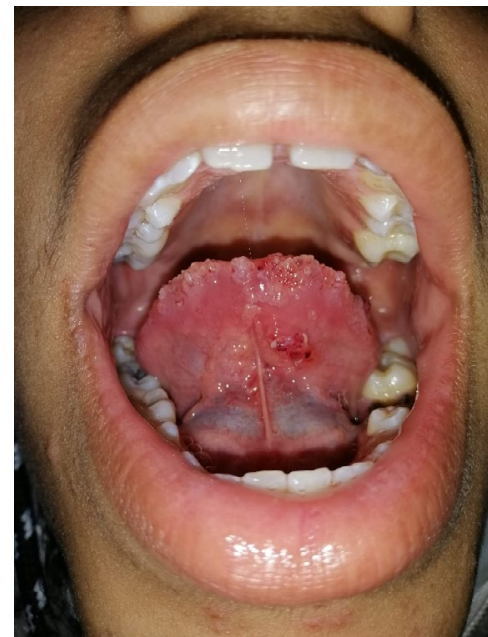

Figure 2. Clinical photos of the tongue showing multiple vesicles with translucent and yellowish contents, sometimes

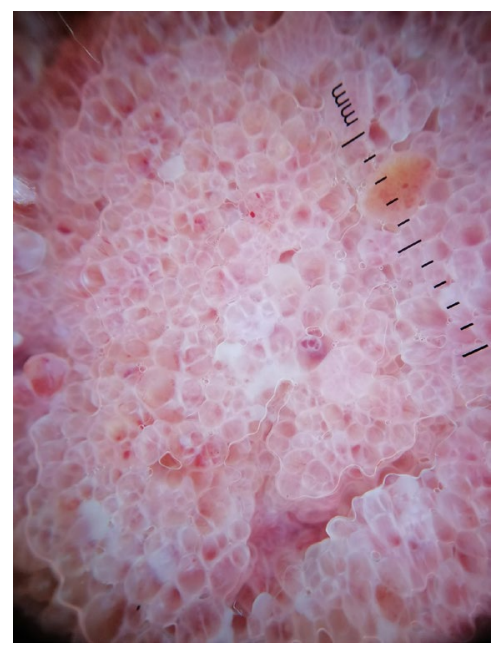

Figure 3. Dermoscopic image showing multiple yellowish and translucent lacuna separated by pale septa

${ }^{\star}$ Correspondence to: Issoual K, Department of Dermatology, Hassan II Hospital University, Fez. Morocco, E-mail : khadijaissoual@gmail.com

Received: February 07, 2020; Accepted: February 25, 2020; Published: March 03,2020 


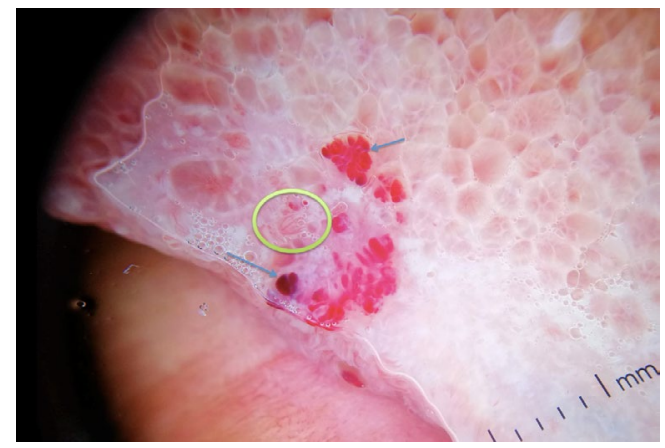

Figure 4. In addition to the yellowish and translucent lacunas, we noticed some reddish or hematic lagoons (blue arrow), with thin linear vessels (yellow circle)

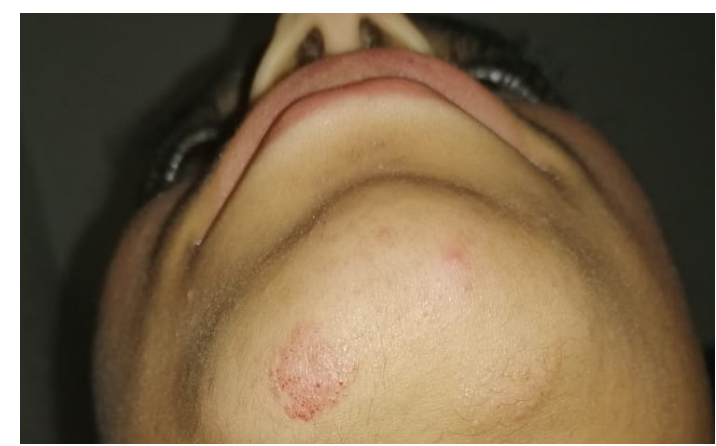

Figure 5. On chin, a small plates of $1 \mathrm{~cm}$ surmounted by small clear vesicles

Copyright: $\odot 2020$ Issoual K. This is an open-access article distributed under the terms of the Creative Commons Attribution License, which permits unrestricted use, distribution, and reproduction in any medium, provided the original author and source are credited. 